\title{
324 Radiochemical Engineering Cells and High Level Vault Tanks Mixed Waste Compliance Status
}

\author{
White Paper \\ Prepared by Pacific Northwest Laboratory ${ }^{1}$ \\ December 29, 1994
}

Contributors include

EA Flores, JT Fulton, SW Gajewski, JH Jarrett, MH Schlender, WA Ross, and PJ Weaver

\section{Summary}

The 324 Building in the Hanford 300 Area contains Radiochemical Engineering Cells and High Level Vault tanks (the "REC/HLV") for research and development activities involving radioactive materials. Radioactive mixed waste within this research installation, found primarily in B-Cell and three of the high level vault tanks, is subject to RCRA/DWR ("RCRA") regulations for storage.

This white paper provides a baseline RCRA compliance summary of MW management in the REC/HLV, based on best available knowledge. The REC/HLV compliance project, of which this paper is a part, is intended to achieve the highest degree of compliance practicable given the special technical difficulties of managing high activity radioactive materials, and to assure protection of human health and safety and the environment.

The REC/HLV was constructed in 1965 to strict standards for the safe management of highly radioactive materials. Mixed waste in the REC/HLV consists of discarded tools and equipment, dried feed stock from nuclear waste melting experiments, contaminated particulate matter, and liquid feed stock from various experimental programs in the vault tanks. B-Cell contains most of these materials. Total radiological inventory in B-Cell is estimated at $3 \mathrm{MCi}$, about half of which is potentially "dispersible," that is, it is in small pieces or mobile particles. Most of the mixed waste currently in the REC/HLV was generated or introduced before mixed wastes were subjected to RCRA in 1987.

'Pacific Northwest Laboratory is operated for the U.S. Department of Energy by Battelle Memorial Institute under Contract DE-ACO6-76RLO 1830. 
It is not clear whether the REC/HLV has interim status; however, it is clear that measures need to be taken to bring the MW management within this facility as close to compliance with RCRA regulations as practicable. This presents significant technical challenges, because manned entry, normal inspection practices, and ready physical management of these materials is prohibited by high radioactivity levels and the limitations of remote-handling equipment and nuclear criticality considerations. Additional constraints are the lack of approved methods of packaging and transporting these wastes and the absence of a RCRA high activity mixed waste storage or disposal facility.

DOE-RL and PNL have taken significant interim actions, including collection and consolidation of much of the dispersible mixed wastes and removal of significant amounts of low level radioactive-only wastes that have a disposal pathway. The physical integrity of the facility is high and the mixed wastes are secure within the REC/HLV. The dispersible waste, however, presents a serious concern for potential release to the environment under a worst-case seismic event scenario.

An examination of the RCRA storage regulations shows that the mixed waste storage conditions at the REC/HLV are generally compliant with regard to basic operating records, preparedness and prevention, security, process knowledge of wastes, and satellite accumulation outside the cells. However, the REC/HLV is not in full compliance with requirements for inspection (RCRA visual inspections not possible), training, labeling, container management, and satellite accumulation inside the B-Cell.

PNL and DOE-RL are moving aggressively to find ways to meet the basic intent of each of the RCRA regulations for storage of these materials, even if the radiological concerns prevent conventional "strict compliance." Alternative methods for removing these materials to a more acceptable location farther from the Columbia River are being identified. A closure plan will be developed, and cleanout of the REC/HLV will be diligently continued. The Department of Ecology and EPA will be closely consulted to determine acceptable interim compliance measures and throughout cleanout and closure operations. 


\section{DISCLAIMER}

This report was prepared as an account of work sponsored by an agency of the United States Government. Neither the United States Government nor any agency thereof, nor any of their employees, make any warranty, express or implied, or assumes any legal liability or responsibility for the accuracy, completeness, or usefulness of any information, apparatus, product, or process disclosed, or represents that its use would not infringe privately owned rights. Reference herein to any specific commercial product, process, or service by trade name, trademark, manufacturer, or otherwise does not necessarily constitute or imply its endorsement, recommendation, or favoring by the United States Government or any agency thereof. The views and opinions of authors expressed herein do not necessarily state or reflect those of the United States Government or any agency thereof. 


\section{DISCLAIMER}

Portions of this document may be illegible in electronic image products. Images are produced from the best available original document. 


\section{Acronyms}

AEA Atomic Energy Act of 1954 (42 U.S.C. 2001 et seq.)

ALARA as low as reasonably achievable

BCCP B-Cell Cleanout Project

CERCLA Comprehensive Environmental Response, Compensation, and Liability Act

CFR Code of Federal Regulations

CNWVP Commercial-Nuclear Waste Vitrification Program

CWC Central Waste Complex

DOE U.S. Department of Energy

DOT U.S. Department of Transportation

DWR Dangerous Waste Regulations

EPA U.S. Environmental Protection Agency.

ES\&H environment, safety, and health

FR Federal Register

FRG Federal Republic of Germany

FY fiscal year

HCRP Hot-Cell Restoration Program

HEPA high efficiency particulate air

HLV high level vault

HLW high level waste

HW hazardous waste

LDR land disposal restrictions

LLV low level vault

LLW low level waste

MOU Memorandum of Understanding

MW mixed waste

NWTP Nuclear Waste Treatment Program

PNL Pacific Northwest Laboratory

RCRA Resource Conservation and Recovery Act

$R \& D \quad$ research and development

REC Radiochemical Engineering Cells

RH-LLW Remote Handled Low Level Waste

RLFCM Radioactive Liquid-Fed Ceramic Melter

RLWS Radioactive Liquid Waste System

RMW radioactive mixed waste

SAR Safety Analysis Report

SARA Superfund Amendments and Reauthorization Act of 1986

SCW special case waste

SNF Spent Nuclear Fuel

TPA Tri-Party Agreement (Federal Facility Compliance Agreement among DOE, EPA, and Washington State Department of Ecology 
TCLP Toxicity Characteristic Leaching Procedure

TRU transuranic

USQ unresolved safety question

WAC Washington Administrative Code

WESF Waste Encapsulation and Separation Facility

WHC Westinghouse Hanford Company 


\section{Contents}

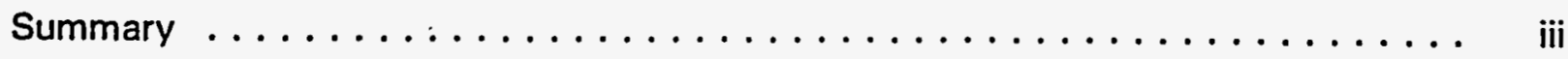

Acronyms $\ldots \ldots \ldots \ldots \ldots \ldots \ldots \ldots \ldots \ldots \ldots \ldots \ldots \ldots \ldots \ldots \ldots \ldots$

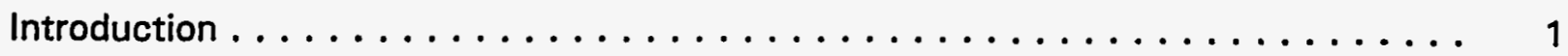

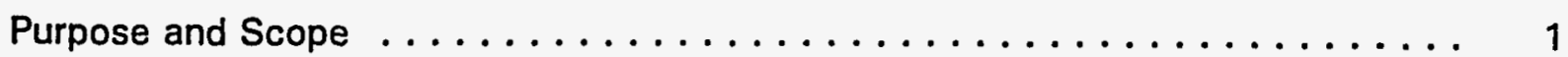

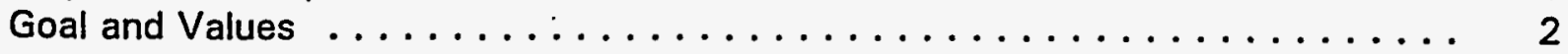

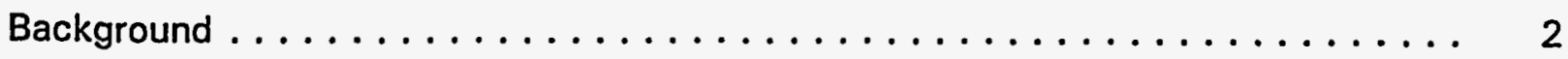

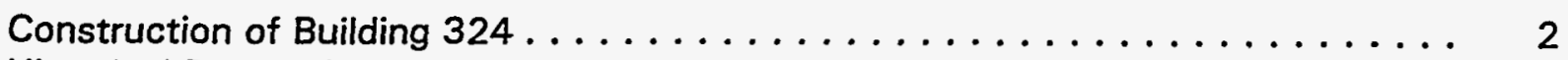

Historical Research, Development and Demonstration Activities in the

Radiochemical Engineering Cells and High Level Vault Tanks . . . . . . . . . 8

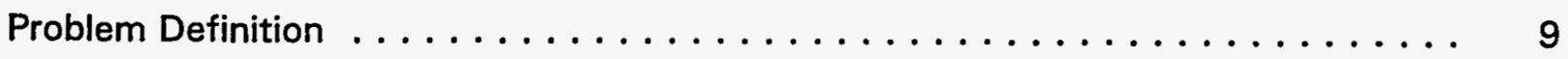

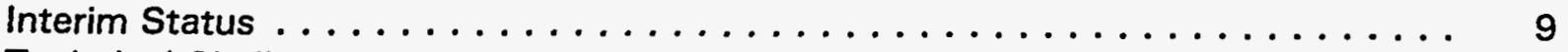

Technical Challenges $\ldots \ldots \ldots \ldots \ldots \ldots \ldots \ldots \ldots \ldots$

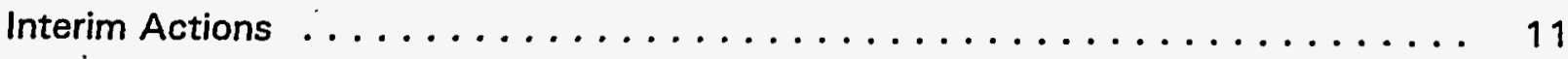

Mixed Waste Inventory . . . . . . . . . . . . . . . . . . 12

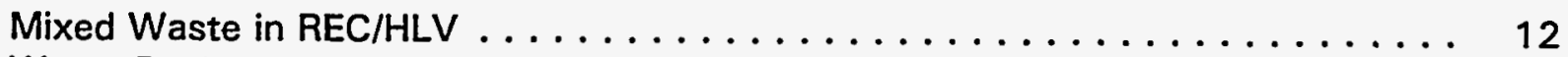

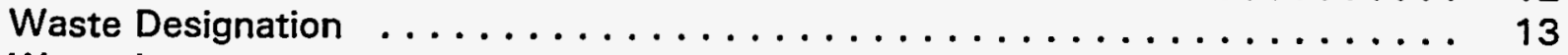

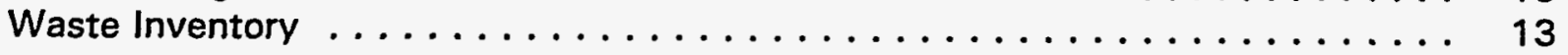

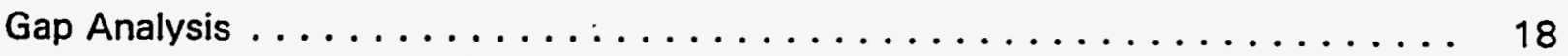

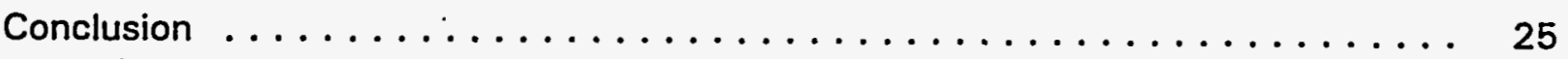

Appendix A - Locator and Topographical Maps of Building $324 \ldots \ldots \ldots$

Appendix B - Design Information on the B-Cell . . . . . . . . . . . 28

Appendix C - Vault Tanks ........................... 29

Appendix D -Relevant Tri-Party Agreement Milestones . . . . . . . . . . 31

Appendix E - Materials Reviewed . . . . . . . . . . . . . . . 32 


\section{Figures}

1324 Building - First Floor Plan $\ldots \ldots \ldots \ldots \ldots \ldots \ldots \ldots \ldots \ldots \ldots \ldots \ldots \ldots \ldots$

2324 Building - Basement Floor Plan .................... 5

3324 Building Radiochemical Engineering Cells . . . . . . . . . . . . . 6

4324 Building High-Level Vault (HLV) and Low-Level Vault (LLV) and

Vault Tanks . . . .......................... 7

5 Locations of Mixed Waste, Special Nuclear Material, and Low Level Waste in B-Cell . . . . . . . . . . . . . . . . . . . . . . . . . 14

\section{Tables}

1 Chronology of Interim Actions in REC/HLV $\ldots \ldots \ldots \ldots \ldots \ldots$

2 Estimated Mixed Waste Inventory in REC and HLV Tanks . . . . . . . . 15

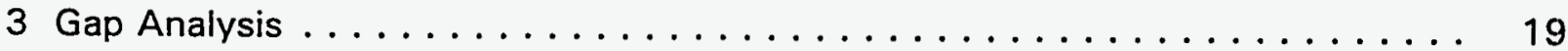




\section{Introduction}

Purpose and Scope. This white paper provides a baseline compliance summary of mixed waste ${ }^{2}$ being managed in the Radiochemical Engineering Cells (REC) and High Level Vault (HLV) tanks in the 324 Building (hereinafter referred to as "REC/HLV"). It includes background, highlights technical issues, and compares current activities to applicable Resource Conservation and Recovery Act (RCRA) waste regulations. This summary is based on best available information on waste management activities. There are some gaps, uncertainties and conflicts in personal recollections and records, particularly with regard to historical activities. We are working to resolve these.

This white paper is one element of the multi-pronged 324 Compliance Project, which includes the following actions:

1. consolidate existing documents and develop history

2. prepare Interim Management Plan

3. achieve compliance with Interim Management Plan

4. prepare RCRA closure plan

- identify technical alternatives for waste disposition

- assess feasibility of "clean closure" for B-Cell and HLV tanks

- integrate RCRA closure with on-going B-Cell cleanout activities

5. prepare status report on actions taken to date to containerize and safely manage dispersibles, and update plan to complete the B-Cell Cleanout Project (BCCP). ${ }^{3}$

\footnotetext{
2"Mixed waste" (MW) is waste that contains both a nonradioactive hazardous/dangerous component and source, special nuclear, or by-product material subject to the Atomic Energy Act. Mixed waste is regulated by the U.S. Environmental Protection Agency (EPA) under the RCRA regulations (40 CFR 260-270) and by the Washington State Department of Ecology under the state equivalent of the RCRA regulations, the Dangerous Waste Regulations (WAC 173-303), hereinafter referred to as "RCRA." Management of the radioactive portion of mixed waste, if classified by the U.S. Department of Energy (DOE) as source, special, or nuclear by-product material, is reserved to DOE.

${ }^{3}$ The BCCP includes the removal of waste material that originated in B-Cell regardless of its location within the REC/HLV.
} 
Goal and Values. The overall goal of the 324 Compliance Project is to bring REC/HLV mixed waste management into compliance with RCRA wherever possible, and where not possible, to ensure that measures are taken that are equally protective of human health and the environment. Decisions and actions will be guided by the following values/ principles:

- Protect public health and safety.

- Ensure worker safety and health, including keeping worker radiation exposures as low as reasonably achievable (ALARA).

- Protect the environment from releases to air, soil, and ground and surface water.

- Minimize the volume of waste that must be disposed.

- Conform to waste acceptance criteria at receiving facility(ies).

- Complete B-Cell cleanout and RCRA closure as soon as possible.

- Minimize impacts to ongoing 324 facility technology development operations in support of Hanford Site and national DOE cleanup activities.

- Ensure future use of the facility for technology development activities.

- Minimize total costs.

- Maximize lessons learned for application to other problem areas in the DOE complex.

\section{Background}

Construction of Building 324. The Pacific Northwest Laboratory (PNL) Building 324 was built in 1965 in the 300 Area of the Hanford Site (see Figures 1 and 2 and Appendix A). Building 324 was constructed to strict nuclear standards to safely house operations involving highly radioactive materials, and to prevent releases to the environment.

Radiochemical Engineering Cells. The 324 Building houses six hot cells. Four of the hot cells--A, B, C and D--are located around a central airlock in the REC (see Figure 3). In 
A-Cell and D-Cell, the floors are lined with stainless steel, and the walls are lined with carbon steel and protective paint. B-Cell and C-Cell are completely lined with stainless steel which is fully welded at the seams. All cell walls are either $4 \mathrm{ft}$-thick, high-density magnetite concrete or $4 \frac{1}{2} \mathrm{ft}$-thick normal concrete. ${ }^{4}$

The REC are equipped with manipulators, remote-operated overhead bridge cranes, remote video cameras, and $4 \mathrm{ft}$-thick leaded glass viewing windows filled with mineral oil (which acts as an optical clarifier). (See Appendix B for additional details on B-Cell.)

Vault Tanks. The 324 Building also contains 8 stainless steel tanks for radioactive liquid storage: 4 low level tanks in the Low Level Vault (LLV) and 4 high level tanks in the High Level Vault (HLV) (see Figure 4). The vaults are lined with stainless steel plates with welded seams, which provide secondary containment. The floor of each vault is sloped to a sump, which has an alarmed liquid detection system. The LLVs are covered with concrete blocks that are $1 \mathrm{ft} 11 \mathrm{in}$. thick; the HLVs are covered with concrete blocks that are $5 \mathrm{ft} 11$ in. thick. (See Appendix $\mathrm{C}$ for additional details.)

\footnotetext{
${ }^{4}$ The 6 in.- thick concrete/rebar cell floors are believed to lie on packed native soil or gravel. There is a crawl space under a portion of the airlock and A-Cell. Further specifics will be provided in the closure plan.
} 


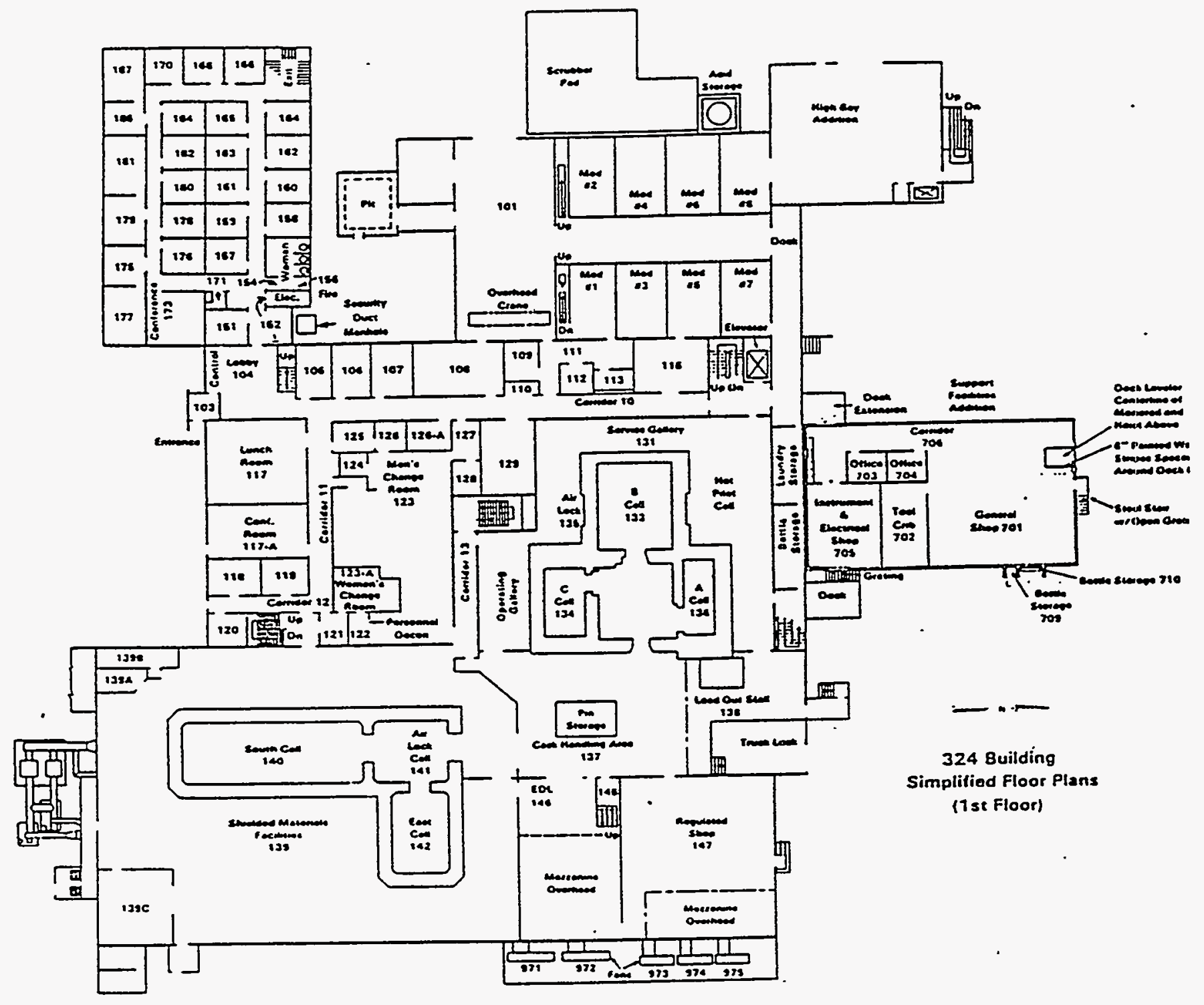

Figure 1. 324 Building - First Floor Plan 


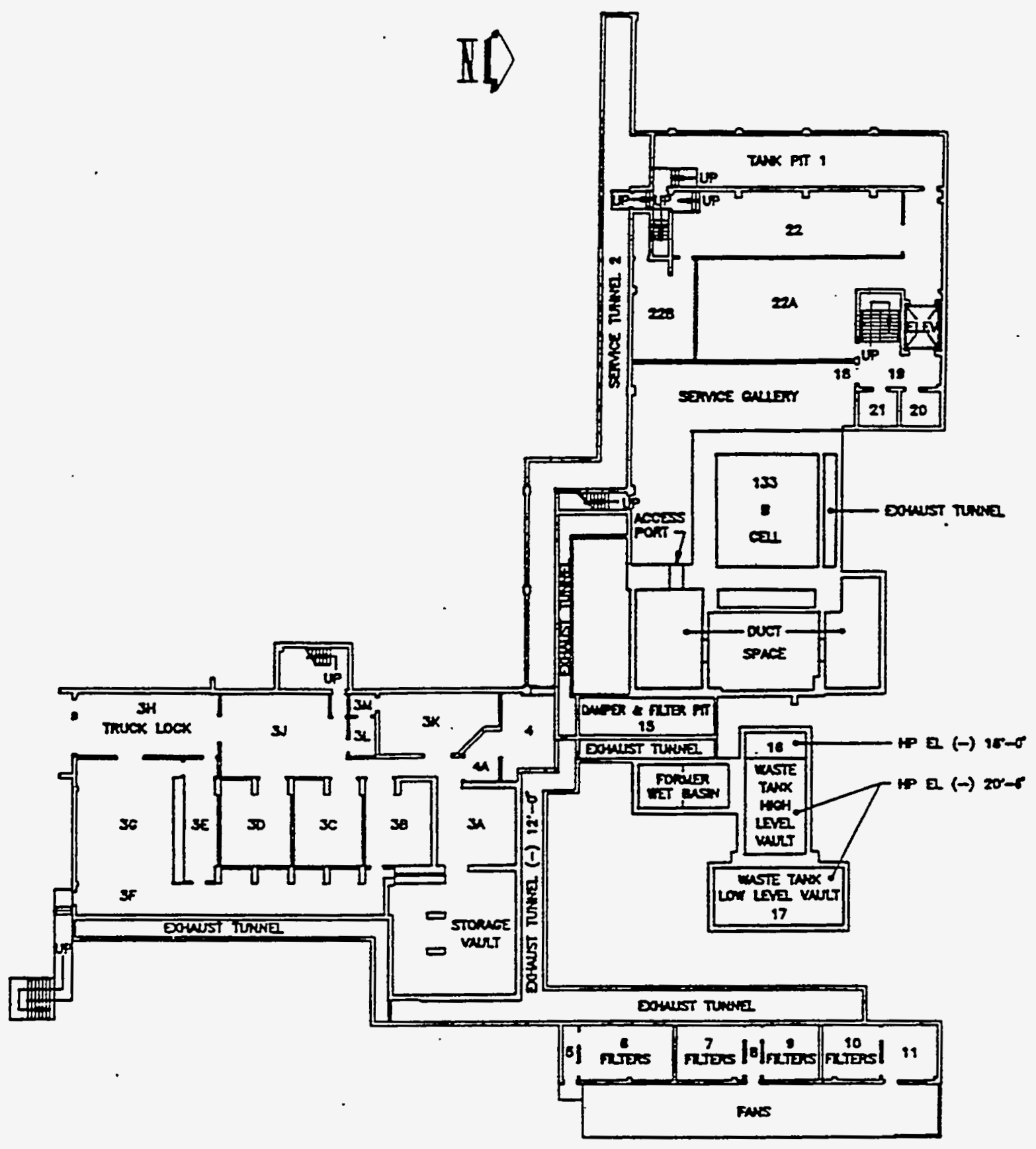

Figure 2. 324 Building - Basement Floor Plan 


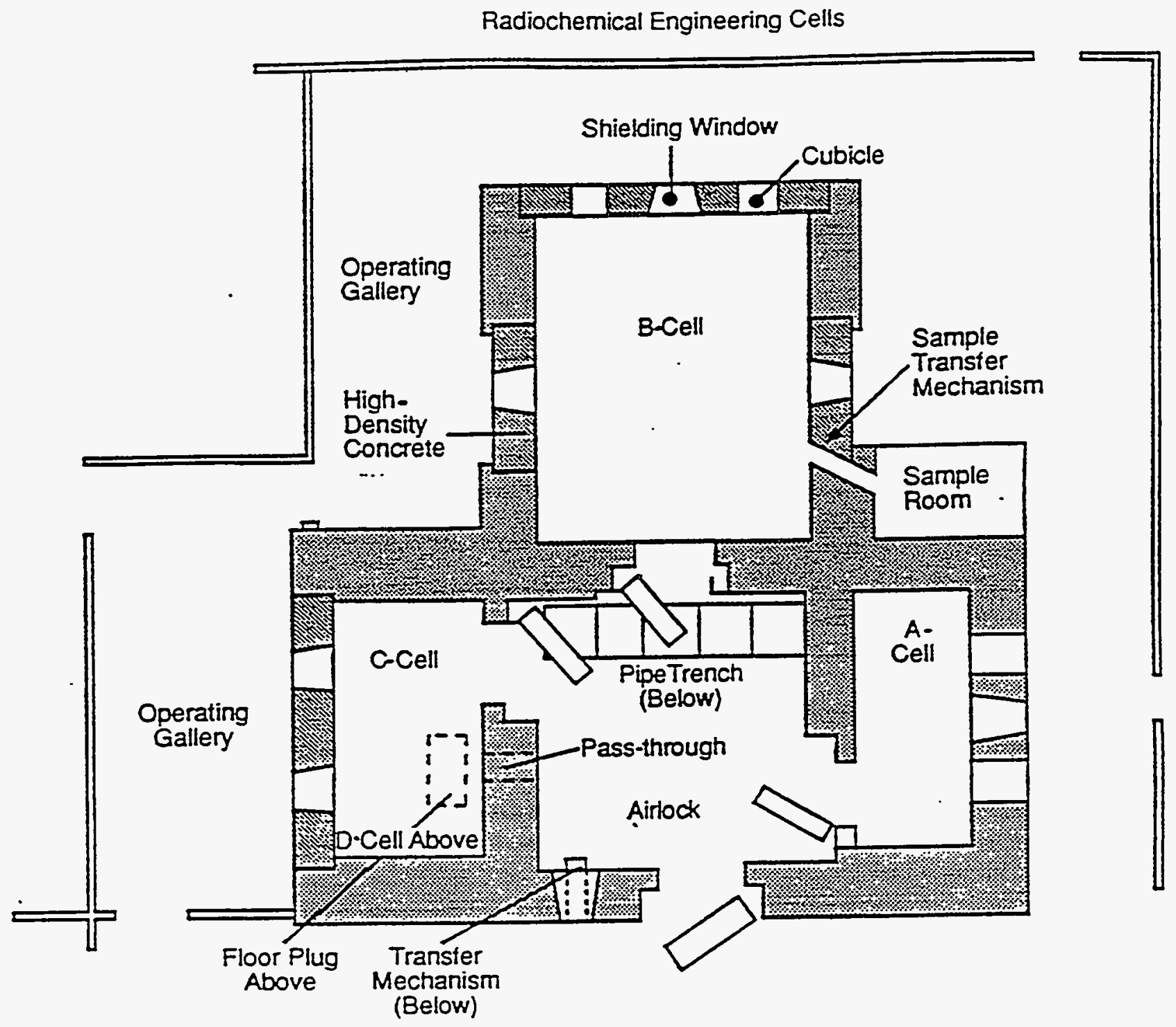

Figure 3. 324 Building Radiochemical Engineering Cells 


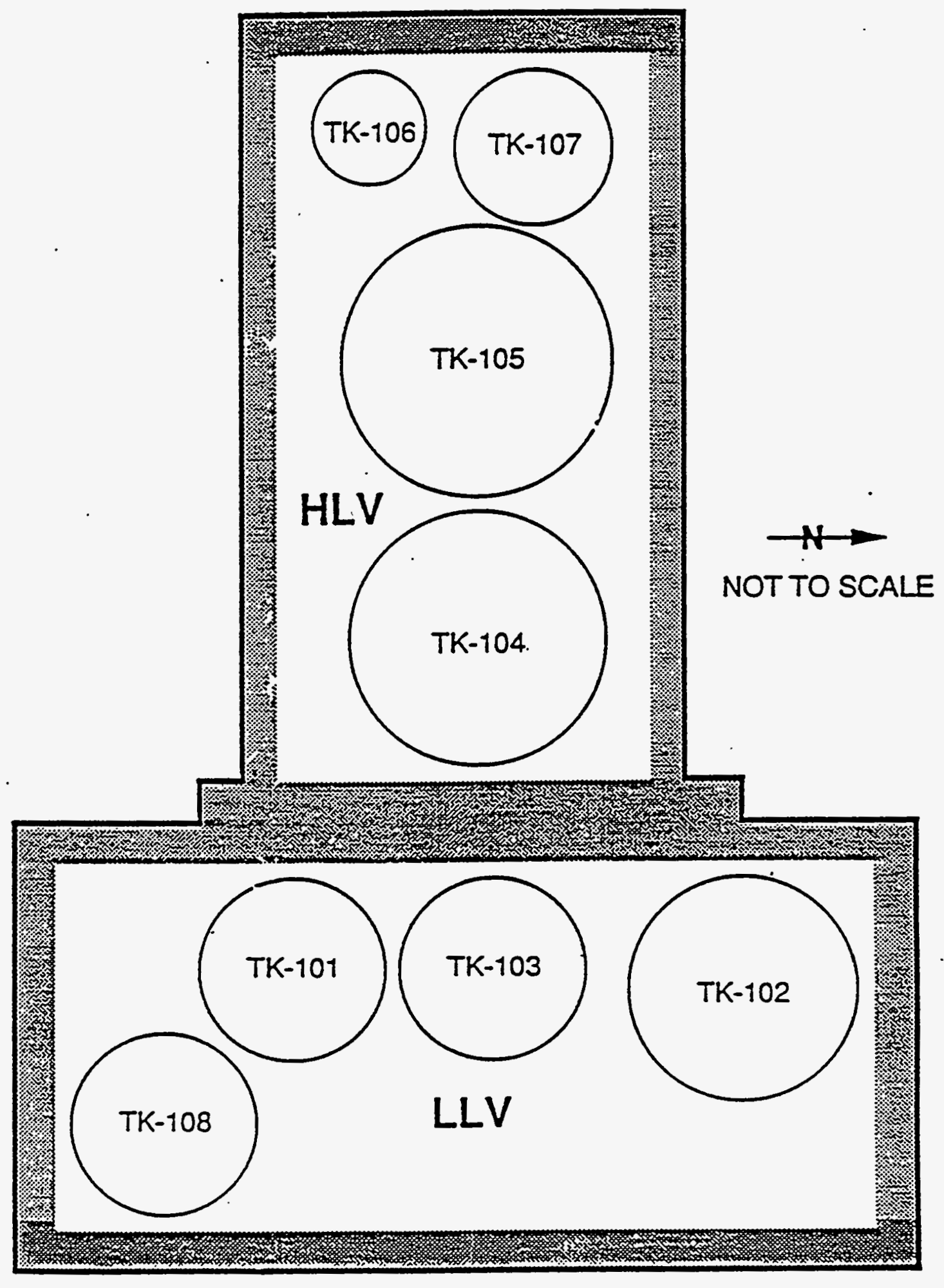

Figure 4. 324 Building High-Level Vault (HLV) and Low-Level Vault (LLV) and Vault Tanks 


\section{Historical Research, Development and Demonstration Activities in the Radiochemical Engineering Cells and High Level Vault Tanks.}

The 324 Building has been used in numerous DOE-sponsored research and development programs. The major activities that have influenced the generation of mixed waste include

- the Waste Solidification Engineering Prototypes Program (completed 1972)

- the development of treatment technologies via the Nuclear Waste Vitrification Project for wastes from Spent Nuclear Fuel (SNF) reprocessing (1979)

- a pilot-scale Radioactive Liquid-Fed Ceramic Melter (RLFCM) testing program in conjunction with Federal Republic of Germany (FRG)(1984-87) ${ }^{5}$

- examination and mechanical testing of irradiated fuel specimens (on-going). .

Most of the materials now in the REC accumulated during the research activities from 1965-1987. During these engineering demonstration activities over a period of $20+$ years, various pieces of equipment (such as tools, manipulator boots, and construction materials) were dropped and liquids (such as feed materials or samples) leaked onto the floor. ${ }^{6}$ In addition, particulate materials (essentially dust) introduced with normal air-flow into the cell became contaminated. (Please see Appendix B for additional detail on air intake and exhaust filtration.)

Operational protocols in the REC were based on the radioactive properties of these materials. These materials were secure within the cell and did not interfere unduly with engineering operations. Because of technical difficulties (as explained below), funding constraints, and safety issues associated with consolidating and/or retrieving, packaging, and/ or transporting the waste materials, they were left in place.

After several years of negotiation between DOE and EPA regarding by-product material management, which resulted in the $1987^{7}$ by-product rulemaking, DOE's mixed waste became subject to RCRA. Because of sampling difficulties and because some of these materials were believed to have experimental or strategic uses, it was not immediately clear whether materials in the REC/HLV were regulated as mixed waste.

\footnotetext{
${ }^{5}$ Melter work was completed in mid FY87.

${ }^{6}$ The total radiological inventory in $\mathrm{B}$-Cell is estimated at $3 \mathrm{MCi}$. An estimated $1.5 \mathrm{MCi}$ are in the potentially dispersible category. A review of logbooks indicates several losses from melter equipment within B-Cell from 1970-1986 associated with the waste solidification off-gas systems and feed systems.

${ }^{7}$ May 1, 1987, 52 FR 15940, 10 CFR 962. EPA issued a Clarification Notice before the ruling, in July of 1986 (51 FR 24504).
} 


\section{Problem Definition}

Interim Status. It is not clear whether REC/HLV has RCRA interim status which would allow mixed waste to be stored over 90 days. The Hanford Site is covered by an "umbrella" RCRA permit, and multiple Part B modification applications have been and will be submitted on a unit-specific basis. The Physical and Chemical Treatment Test Facilities Part A permit application submitted for the Hanford Site covers both storage and treatment associated with treatment test facility activities, including the 324 REC, but does not mention the HLV tanks. Ecology, EPA, PNL and DOE are currently examining the issue of whether or not the REC and vault tanks are covered under interim status.

Technical Challenges. Applicable RCRA regulations were not designed for nontraditional facilities such as REC/HLV or for the non-traditional wastes being managed in REC/HLV. These non-traditional facilities and wastes present numerous technical challenges:

1. Manned entry into cells is prohibited because of the high radiation dose rate (up to 1 million $\mathrm{R} / \mathrm{hr}$ ) from the radioactive material inventory.

2. Manned entry into vault tanks is also prohibited because of high levels of radiation.

3. There is no RCRA interim status or permitted treatment, storage or disposal facility anywhere in the United States that can accept these high activity, remotely handled mixed wastes in their current form or packaging.

4. Ultimate disposal facility waste acceptance criteria have not been established yet.

5. Currently, there is no Department of Transportation (DOT)-approved method for offsite transportation of the bulk aqueous solutions contained in the HLV tanks.

6. There are no approved transportation containers (which meet regulatory guidelines) at Hanford, and perhaps anywhere, for the liquids. ${ }^{8}$

7. Managing nuclear materials presents criticality problems (limits consolidation, spacing and containment geometry).

8. Some of the mixed waste in B-Cell is highly dispersible.

\footnotetext{
${ }^{8}$ Packaging and transportation issues are under examination. A Safety Analysis Report (SAR) for Packaging for "bowling ball" casks has been submitted to DOE. Further investigation of possible approved transportation containers/vehicles will be done in support of the alternatives study.
} 
9. Radiolysis (breakdown by high-level radiation) of some of the solid and liquid wastes generates potentially explosive hydrogen gas.

10. Tanks are not readily accessible for sampling. ${ }^{9}$

11. Introduction of equipment and removal of materials is limited by cell and airlock configuration and shielding requirements.

12. Interior space and ability to maneuver are limited because of the large amount of equipment and material and on-going cleanout activities in the cell.

13. Existing remote handling equipment does not permit precise manipulation of materials/ wastes. Old process equipment and equipment racks prohibit ready access to the floor and, thus, much of the mixed waste on the cell floor. Manipulators cannot reach the B-Cell floor and have a weight limit of $25 \mathrm{lb}$ at full extension.

14. Age and condition of equipment (e.g., cranes) present operational problems (reliability).

15. Because of constraints imposed by high levels of radioactivity, standard EPA (SW-846) sample test methods cannot be followed (e.g., sample size limited to 5 grams).

16. Conventional inks and paint on labels tend to become illegible within short periods of time in high-level radioactive fields and labeling must be done remotely (and awkwardly) with manipulators.

17. A variety of waste forms is present. Different waste forms may determine different disposal pathways. Physical handling methods also vary (e.g., liquids versus dispersibles versus solid debris).

18. A portion of the 324 Building may have been built on top of an old disposal pit, which may pose monitoring difficulties under some future final closure scenarios. ${ }^{10}$

The attention, cooperation and involvement of a number of stakeholders (including PNL, Westinghouse Hanford Company [WHC], DOE, Ecology, EPA, the Indian Nations, and the public) will be necessary to address these challenges.

\footnotetext{
${ }^{9}$ There is a remote sampling station in Room 145.

${ }^{10}$ Building 324 is within Operable Unit 300-FF-3 and lies near Operable Unit 300-FF-1. Both of these units are being addressed as Comprehensive Environmental Response, Compensation, and Liability Act (CERCLA) past practice units.
} 


\section{Interim Actions}

PNL and DOE-RL have taken a number of steps to address the mixed waste management problem in REC/HLV (see Table 1 for chronology and Appendix D for relevant TriParty Agreement [TPA] milestone summary). Cleanout of the hot cells to eliminate the unacceptable radiological hazard associated with the dispersible material in the B-Cell was initiated in 1988 , with completion expected by the year 2000 . Cleanout activities include size reduction, packaging, removing, and disposing of equipment and radioactive materials generated during research programs. Final cleaning will allow resumption of research and development activities.

By the end of FY94, $63 \%$ of the floor area had been cleared of potentially dispersible mixed waste. These dispersible wastes were consolidated and containerized within the B-Cell. In addition, a total of 52 shipments (1 from C-Cell and 51 from B-Cell) of remote handled-low level waste (RH-LLW) had been made to the 200W LLW Burial Ground. All of this RH-LLW was non-RCRA regulated. Ten cubic feet of contact-handled mixed waste (lead solids) has also been shipped to the Hanford Site Central Waste Complex (CWC). Removal of these RH-LLW and contact-handled mixed waste materials was possible because there were appropriate disposal transportation modes and storage/disposal facilities available.

Table 1. Chronology of Interim Actions in REC/HLV

\begin{tabular}{|c|c|}
\hline $\begin{array}{l}\text { Fiscal. } \\
\text { Year. }\end{array}$ & $\therefore, \quad, \cdots, \cdots$ \\
\hline 1987 & - Hot Cell Restoration Program planning began. \\
\hline 1988 & - B-Cell and C-Cell cleanout initiated. \\
\hline 1989 & - Miscellaneous LLW packaged and removed to allow start of processing equipment removal. \\
\hline 1990 & - C-Cell cleanout completed. One shipment of RH-LLW made. \\
\hline 1991 & $\begin{array}{l}\text { - Safety implications of potentially dispersible contamination examined. } \\
\text { - Funding to support cleanout of B-Cell aggressively sought and secured by DOE-RL-RDD. } \\
\text { - } 10 \% \text { of floor area cleared; } 9 \text { shipments of RH-LLW made. }\end{array}$ \\
\hline 1992 & $\begin{array}{l}\text { - Draft SAR shows unacceptable risk from dispersible contamination in "worst case" seismic event. } \\
\text { - Regulatory Analysis and Management Plan for mixed waste produced. } \\
\text { - } 20 \% \text { (additional } 10 \% \text { over prior year) of floor area cleared; } 12 \text { RH-LLW shipments made. }\end{array}$ \\
\hline 1993 & $\begin{array}{l}\text { - Revised B-Cell cleanout plan submitted. } \\
\text { - Unresolved Safety Question (USQ) declared over melter feed loss and B-Cell cleanout operations. } \\
\text { - Laboratory analysis of mixed waste available. } \\
\text { - } 52 \% \text { of floor area cleared; } 25 \text { RH-LLW shipments made. }\end{array}$ \\
\hline 1994 & $\begin{array}{l}\text { - B-Cell USQ resolution document prepared, reviewed by DOE, and submitted to PNL for comment resolution. } \\
\text { - AT Kearney Mixed Waste Management Plan for } 324 \text { Building REC and Tank Vaults drafted. } \\
\text { - } 63 \% \text { of floor area cleared; } 5 \text { RH-LLW shipments made. } \\
\text { - Document package submitted to Ecology (see Appendix E). }\end{array}$ \\
\hline
\end{tabular}




\section{Mixed Waste Inventory}

Mixed Waste in REC/HLV. Most of the mixed waste in REC/HLV was generated as a result of research and development (R\&D) operations conducted from 1965 to 1987 (when RLFCM ended).

Radiochemical Engineering Cells. B-Cell contains highly radioactive mixed waste generated from these historical research programs (see Figure 5). This waste is being recovered during cleanout activities and stored in B-Cell and D-Cell (D-Cell storage includes B-Cell refractory brick and mineral oil from a cracked B-Cell window) until further consolidation and packaging begins. ${ }^{11}$ (See inventory matrix [Table 2] below for details.)

Current activities in the cells include some shuttling of material and equipment to make room for cleanout operations. Other R\&D activities are also conducted, including small scale treatability studies (RCRA requirements for treatability study sample exemptions are being met). No new materials are being brought into the cells without a predetermined mixed waste disposal pathway and an approved, funded mixed waste disposal plan. However, future B-Cell cleanout activities may result in the discovery of additional materials which may be characterized as mixed waste. Size reduction and other cleanout activities may result in the generation of additional mixed waste, such as cuttings, slag, or pieces of equipment with no further utility.

Vault Tanks. The HLV and LLV tanks have been used as holding tanks for feed solutions, feedstock tanks for process solutions, and collection tanks for process effluent. The LLV tanks are used as "pass-through" tanks for sending wastes to the double shell storage tanks in the 200 Area via the Radioactive Liquid Waste System (RLWS) receiving facility (340 Building). Three of the four HLV tanks $(104,105$, and 107) currently contain leftover research feed materials which were declared mixed waste when there was no further identified use for them.

No new waste is currently being added to the HLV tanks. ${ }^{12}$ Documented process knowledge and review of operating records indicate there is no mixed waste in Tk-106 in the HLV or in any of the LLV tanks.

\footnotetext{
"An electropolisher in A-Cell contains approximately 600 gal of phosphoric acid material. It may be used to decontaminate FRG and Special Case Waste (SCW) (non-mixed waste greater than Class C, remote-handled transuranic [TRU], HLW, SNF) overpacks from B-Cell cleanout.

${ }^{12}$ Heat generated by radionuclides in the waste solution and air flow through the tanks increase the evaporation rate of water in the tanks. Therefore, make-up water is periodically added to the vault tanks to maintain solubility levels and prevent the waste material from drying out.
} 
Waste Designation. Based on process knowledge, all of the designated mixed wastes in REC/HLV are currently classified under RCRA as "characteristically hazardous" (because of heavy metal contamination or corrosivity), with the exception of a small volume of cleaning solvent contaminated rags, which are considered "listed" waste. None of the mixed wastes in REC/HLV are classified as ignitable or reactive. None of the wastes are incompatible with each other.

Waste Inventory. Table 2 summarizes best available knowledge on source, type, and preliminary waste designations under RCRA; basis for designation (i.e., whether designation as a RCRA waste is based on process knowledge or analytical data); waste form (liquid/solid); and estimated amounts of mixed waste (or potential mixed waste) currently located in the B-Cell, D-Cell and HLV tanks. The quantities reported here are under review. Wastes listed in italics are those which have not been designated as mixed waste. 


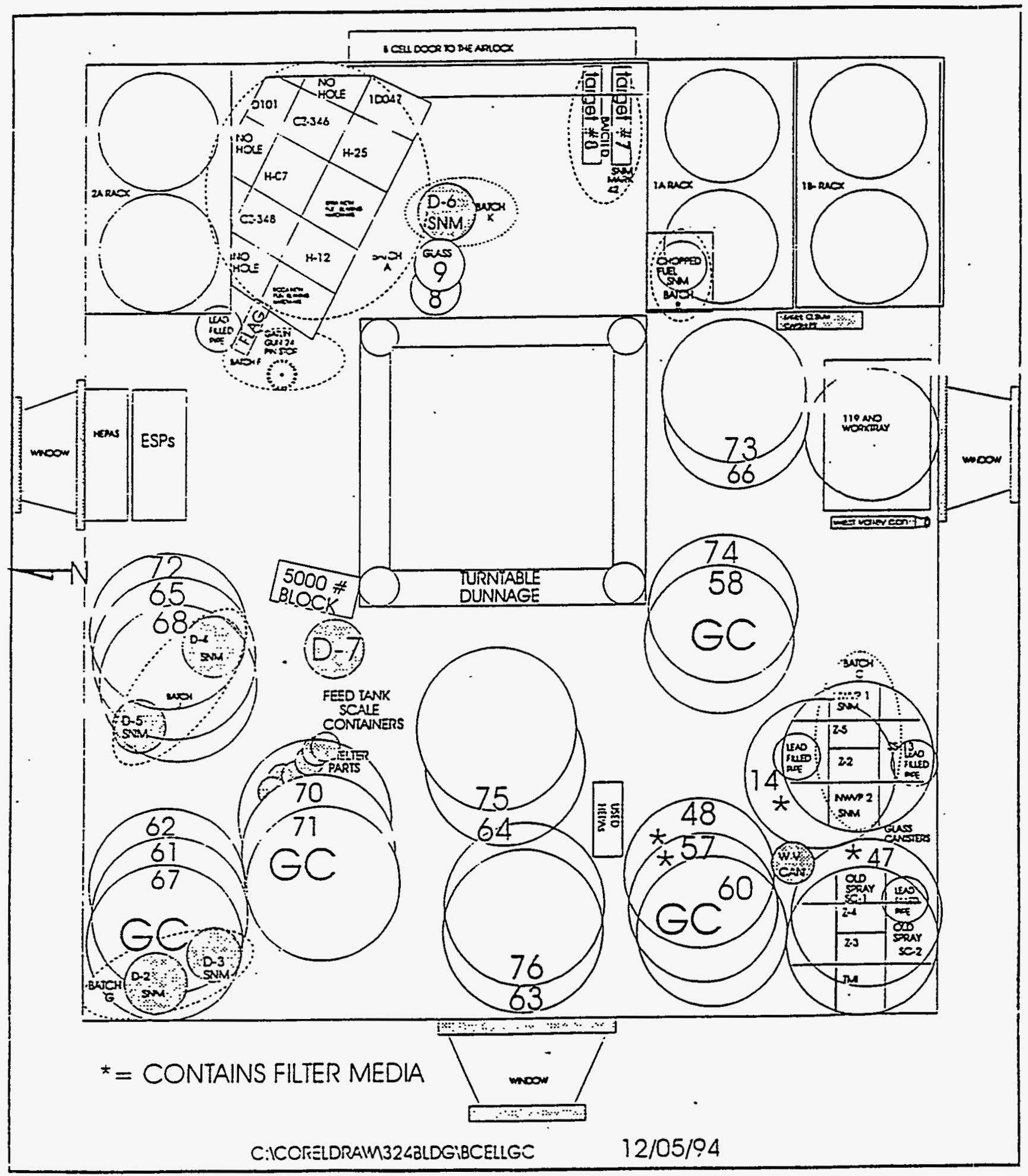

Figure 5. Locations of Mixed Waste, Special Nuclear Material, and Low Level Waste in B-Cell 
Table 2. Estimated Mixed Waste Inventory in REC and HLV Tanks

\begin{tabular}{|c|c|c|c|}
\hline Waste Source & $\begin{array}{l}\text { Waste Type - Waste Form, Waste } \\
\text { Codes and (Basis for Designation) }\end{array}$ & $\begin{array}{l}\text { Amount } \\
\text { Estimate }\end{array}$ & Location/Comments \\
\hline \multicolumn{4}{|l|}{ B-Cell and D-Cell } \\
\hline $\begin{array}{l}\text { Tools, equipment, pieces of metal that dropped on floor during } \\
\text { operations; dust and particulates contaminated with sporadic- } \\
\text { ally released material (feed solution which contained heavy } \\
\text { metals) from process equipment. }\end{array}$ & $\begin{array}{l}\text { Dispersible" Debris - Solid } \\
\text { D005, D006, D007, D008, D010, } \\
\text { D011, WT01 } \\
\text { (Analytical testing of } 1 \text { sample) }\end{array}$ & $88 \mathrm{ft}^{3}$ & $\begin{array}{l}37 \mathrm{ft}^{3} \text { collected in 55-gal drums. } \\
\text { Remainder on floor. Will be repackaged } \\
\text { into 3-gal engineered containers. MW } \\
\text { cleaning residues, if any, will be managed } \\
\text { appropriately. Large metallic portions will } \\
\text { be decontaminated and disposed of as } \\
\text { non-mixed waste. }\end{array}$ \\
\hline $\begin{array}{l}\text { Feed solution from RLFCM testing which has dried out and } \\
\text { has been containerized. The original melter feed contained } \\
\text { lead and chrome in solution. The source of liquid used in } \\
\text { melter operations is believed to be B Plant (located in the } \\
200 \text { Area). B Plant was used to remove cesium and strontium } \\
\text { from supernate pumped out of the single shell tanks. (Note: } \\
\text { some other feed tanks were supposedly flushed and rinsed, } \\
\text { but may contain dried heels). }\end{array}$ & $\begin{array}{l}\text { Dried Melter Feed-Solid } \\
\text { D007, D008, WTO1 } \\
\text { (Process knowledge) }\end{array}$ & $6 \mathrm{ft}^{3}$ & Fifteen 3-gal containers located in B-Cell. \\
\hline $\begin{array}{l}\text { Liquid metal alloy (believed to be } \mathrm{Pb}-\mathrm{Cd} \text { ) used to seal the inter- } \\
\text { face between the melter and the canister turntable which } \\
\text { received the glass. }\end{array}$ & $\begin{array}{l}\text { Liquid Metal Seal-Solid } \\
\text { D006, D008, WT01 } \\
\text { (Process knowledge) } \\
\end{array}$ & $<7 \mathrm{ft}^{3}$ & $\begin{array}{l}\text { B-Cell. Referred to as "liquid metal" } \\
\text { because of low melting point }\left(158^{\circ} \mathrm{F}\right) \text {. }\end{array}$ \\
\hline Mineral oil which leaked out of broken B-Cell viewing window. & $\begin{array}{l}\text { Oil Absorption Material-Solid } \\
\text { WT02 } \\
\text { (Process knowledge) }\end{array}$ & $<7 \mathrm{ft}^{3}$ & $\begin{array}{l}\text { D-Cell. A clay-based absorbent was used, } \\
\text { and then the absorbent material was } \\
\text { scooped into a drum (July 1994). }\end{array}$ \\
\hline
\end{tabular}

Dispersibles in B-Cell are solid particulates of contamination that may be released in an event in which HEPA filtration is lost. The mobility of the dispersible particulates was identified as a problem in a "worst casen" seismic accident scenario analyzed in the building's January 1992 Draft SAR. The safety concern is based on the potential radiation exposure should a portion of this particulate contamination reach the outside environment. 
Table 2. (contd)

\begin{tabular}{|c|c|c|c|}
\hline Waste Source & $\begin{array}{l}\text { Waste Type - Waste Form, Waste } \\
\text { Codes and (Basis for Designation) }\end{array}$ & $\begin{array}{l}\text { Amount } \\
\text { Estimate }\end{array}$ & Location/Comments \\
\hline $\begin{array}{l}\text { Lining of an experimental melter used in B-cell. The brick } \\
\text { consists of a chrome oxide spinel. }\end{array}$ & $\begin{array}{l}\text { Refractory Brick-Solid } \\
\text { NOT YET DESIGNATED AS MIXED } \\
\text { WASTE: Testing required. } \\
\text { POSsibly DOO7. }\end{array}$ & $10 \mathrm{ft}^{3}$ & $\begin{array}{l}\text { B-Cell and D-Cell containers. Under normal } \\
\text { melter conditions, the refractory brick does } \\
\text { not fail the Toxicity Characteristic Leaching } \\
\text { Procedure (TCLP) test because the chrome } \\
\text { is in a non-leachable matrix. It is unknown } \\
\text { if high activity radioactive work causes the } \\
\text { chrome to become leachable. }\end{array}$ \\
\hline $\begin{array}{l}\text { High-Efficiency Particulate Air (HEPA) filter media used for cell } \\
\text { ventilation and filtration, generated as part of BCCP. Some } \\
\text { cell activities can cause dispersibles contaminated with heavy } \\
\text { metals to become airborne. The filter media has been } \\
\text { removed from the filter frames. }\end{array}$ & $\begin{array}{l}\text { Used HEPA filters-Solid } \\
\text { NOT YET DESIGNATED AS MIXED } \\
\text { WASTE- Testing required. } \\
\text { Possibly DOO7, DOO8. }\end{array}$ & $\begin{array}{l}177 \mathrm{ft}^{3} \\
\text { (Several } \\
\text { filters) }\end{array}$ & $\begin{array}{l}\text { B-Cell grout containers. } \\
\text { Since 1991, an electrostatic precipitator } \\
\text { system pre-filters air prior to HEPA filters, } \\
\text { which may result in subsequently gener- } \\
\text { ated HEPA filters being non-RCRA regu- } \\
\text { lated. When the electrostatic precipitator } \\
\text { system is cleaned, the particulate is } \\
\text { washed onto the floor with the } \\
\text { dispersibles. }\end{array}$ \\
\hline \multicolumn{4}{|l|}{ Satellite Accumulation } \\
\hline $\begin{array}{l}\text { Shielding and counter balances in the form of bricks, sheet, } \\
\text { wool, shot, and poured lead. Dunnage is present as lead } \\
\text { bricks, shot, poured lead. Amount of lead shot is small }\left(3 \mathrm{ft}^{3}\right) \text {. }\end{array}$ & $\begin{array}{l}\text { Waste Elemental Lead - Solid } \\
\text { DO08, WT01 } \\
\text { (Process knowledge) }\end{array}$ & $\begin{array}{l}28 \mathrm{ft}^{3} \\
\left(10 \mathrm{ft}^{3}\right. \\
\text { collected })\end{array}$ & $\begin{array}{l}\text { Satellite accumulation areas in B-Cell, and } \\
\text { in REC truck lock. Contact-handled } \\
\text { shipped to Hanford CWC. Remote-handled } \\
\text { in satellite accumulation area within B-Cell. } \\
\text { Some may be cleaned and reused or } \\
\text { recycled during BCCP. }\end{array}$ \\
\hline $\begin{array}{l}1,1,1 \text { Trichloroethane used as cleaning material in REC sup- } \\
\text { port areas outside of hot cells. Solvent is sprayed on equip- } \\
\text { ment or rags and used to decontaminate manipulators. }\end{array}$ & $\begin{array}{l}\text { Cleaning Material-Solid } \\
\text { F002, WPO2, WTO2 } \\
\text { (Process knowledge) }\end{array}$ & $<7 \mathrm{ft}^{3}$ & $\begin{array}{l}\text { In Room } 147 \text {. Very small amounts being } \\
\text { generated. Contact handled, will be } \\
\text { shipped to Hanford CWC when satellite } \\
\text { accumulation limits met. This is the only } \\
\text { listed waste. }\end{array}$ \\
\hline
\end{tabular}


Table 2. (contd)

\begin{tabular}{|c|c|c|c|}
\hline Waste Source & $\begin{array}{l}\text { Waste Type - Waste Form, Waste } \\
\text { Codes and (Basis for Designation) }\end{array}$ & $\begin{array}{l}\text { Amount } \\
\text { Estimate }\end{array}$ & Location/Comments \\
\hline \multicolumn{4}{|l|}{ High Level Vault Tanks } \\
\hline $\begin{array}{l}\text { Residual wastes from a waste vitrification technology used to } \\
\text { make FRG logs in the mid-1980s. Originally it was predomi- } \\
\text { nantly }{ }^{137} \mathrm{Cs} \text {, but it also contains some }{ }^{90} \mathrm{Sr} \text { as a result of vari- } \\
\text { ous operations. The strontium solutions from B-Plant (from } \\
\text { WESF work to remove strontium and cesium from the single } \\
\text { shell tanks) contained low levels of plutonium. }\end{array}$ & $\begin{array}{l}\text { Dilute }{ }^{137} \mathrm{Cs} \text { Nitrate Solution-Liquid } \\
\text { D002, D008, WT02 } \\
\text { (Analytical data-total metals and pH) }\end{array}$ & $400 \mathrm{gal}$ & $\begin{array}{l}\text { Tank 104. Tank contains about } 6400 \text { cur- } \\
\text { ies of cesium and strontium. The original } \\
\text { material was transferred to the } 324 \text { Build- } \\
\text { ing from B-Plant as nitrate solutions in } \\
\text { "bowling ball casks." Classified as a Class } \\
3 \text { (C) TRU waste. Approximately } 500 \mathrm{ml} \\
\text { was removed from this tank for use in the } \\
\text { medical isotopes program and now pro- } \\
\text { vides } 90 \mathrm{Y} \text { for cancer research. }\end{array}$ \\
\hline $\begin{array}{l}\text { Residual wastes from the FRG program. Originally } \\
\text { predominantly }{ }^{90} \mathrm{Sr} \text {, but now contains significant }{ }^{137} \mathrm{Cs} \text {. The } \\
\text { radionuclides were originally from B-Plant (WESF work) and } \\
\text { the } 200 \text { Area Tank Farm. The strontium solutions from B- } \\
\text { Plant contained low levels of plutonium. }\end{array}$ & $\begin{array}{l}\text { Dilute }{ }^{90} \mathrm{Sr} \text { Nitrate Solution - Liquid } \\
\text { D002, D008, WTO2 } \\
\text { (Analytical data-total metals and } \mathrm{pH} \text { ) }\end{array}$ & $400 \mathrm{gal}$ & $\begin{array}{l}\text { Tank 105. Tank contains about } 37,000 \\
\text { curies of residual fission product activity } \\
\text { with trace } \mathrm{U} \text { and Pu. Classified as TRU } \\
\text { waste. }\end{array}$ \\
\hline $\begin{array}{l}\text { Some is feed material left over from the Commercial Nuclear } \\
\text { Waste Vitrification Program (CNWVPI conducted in the late } \\
1970 \text { s. Commercial SNF was dissolved in B-Cell, vacuum- } \\
\text { transferred to } 325 \text { for processing, then vacuum-transferred } \\
\text { back to } 324 \text { for vitrification. Some Tk-106 feed stock was } \\
\text { transferred to Tk-107. }\end{array}$ & $\begin{array}{l}\text { Process Feedstock Solution-Liquid } \\
\text { D002, D007, WTO2 } \\
\text { (Analytical data) }\end{array}$ & $165 \mathrm{gal}$ & $\begin{array}{l}\text { Tank } 107 \text {. Contains about } 79,000 \text { curies } \\
\text { of residual fission product activity with } \\
\text { trace } \mathrm{U} \text { and } \mathrm{Pu} \text {. }\end{array}$ \\
\hline
\end{tabular}




\section{Gap Analysis}

Table 3 summarizes the applicable RCRA regulatory requirements and provides a "snapshot" of the corresponding current status of mixed waste management in REC/HLV. PNL is still in the process of reviewing compliance status.

This white paper does NOT address actions which will be taken to achieve compliance with the RCRA requirements. Gaps are being addressed in the interim management plan being developed as part of this project. 
Table 3. Gap Analysis

\begin{tabular}{|c|c|c|c|}
\hline Applicable Regulation & Regulatory Requirement & Current Status & Comments \\
\hline $\begin{array}{l}\text { Land Disposal Restrictions (LDR) } \\
\text { WAC-173-303-140 } \\
40 \text { CFR } 268\end{array}$ & $\begin{array}{l}\text { Notification and certification forms, treat- } \\
\text { ment to standards for land disposal. } \\
\text { Annual report required for LDR waste } \\
\text { stored }>1 \text { year. }\end{array}$ & $\begin{array}{l}\text { Need to be added to sitewide LDR inven- } \\
\text { tory report in } 4 / 95 \text {. Notification and } \\
\text { certification forms are being used. }\end{array}$ & No land disposal takes place. \\
\hline $\begin{array}{l}\text { EPA ID Number } \\
\text { WAC-173-303-280 } \\
40 \text { CFR } 262.12\end{array}$ & Obtain EPA identification number. & $\begin{array}{l}\text { Hanford Site EPA ID No: WA7890008967 } \\
\text { (Form } 2 \text { submitted } 8 / 14 / 80 \text { ). }\end{array}$ & \\
\hline $\begin{array}{l}\text { Notice of Intent } \\
\text { WAC-173-303-281 }\end{array}$ & File Part A permit application. & $\begin{array}{l}\text { On } 05 / 19 / 88 \text {, PNL filed three Form } 3 \text { 's for } \\
\text { thermal, physical/chemical, and biological } \\
\text { treatment test facilities. No Form } 3 \text { has } \\
\text { been filed specifically for REC/HLV, but the } \\
\text { REC was included in the Physical/Chemical } \\
\text { Form } 3 \text { as revised on } 06 / 14 / 91 \text {. The HLV } \\
\text { tanks were not included on this Form } 3 \text {. }\end{array}$ & $\begin{array}{l}\text { Hanford sitewide permit effective on } \\
09 / 24 / 94 \text { only incorporates five final } \\
\text { status units and closures, and does } \\
\text { not address REC/HLV operations. }\end{array}$ \\
\hline $\begin{array}{l}\text { Siting Criteria } \\
\text { WAC-173-303-282 }\end{array}$ & $\begin{array}{l}\text { Initial screening criteria to be considered in } \\
\text { siting waste management facilities }\end{array}$ & $\begin{array}{l}\text { Not applicable. Facility was in existence at } \\
\text { the time Dangerous Waste Regulations } \\
\text { (DWR) applied to MW management. }\end{array}$ & \\
\hline $\begin{array}{l}\text { Performance Standards } \\
\text { WAC-173-303-283 }\end{array}$ & $\begin{array}{l}\text { Construction criteria for dangerous waste } \\
\text { Treatment, Storage and Disposal Facilities. }\end{array}$ & $\begin{array}{l}\text { Not applicable, because facility pre-existed } \\
\text { the regulations. However, the building is } \\
\text { believed to meet standards: }\end{array}$ & \\
\hline $\begin{array}{l}\text { Required Notices } \\
\text { WAC-173-303-290 }\end{array}$ & Import/export notices. & Not applicable to current operations. & No wastes received from offsite. \\
\hline $\begin{array}{l}\text { Waste Minimization } \\
\text { RCRA Statute }\end{array}$ & $\begin{array}{l}\text { Program in place to reduce volume and } \\
\text { toxicity. }\end{array}$ & $\begin{array}{l}\text { 5/94 Hanford Site Waste Mínimization and } \\
\text { Pollution Prevention Awareness Program } \\
\text { Plan. PNL has waste minimization plans. }\end{array}$ & \\
\hline $\begin{array}{l}\text { Haz. Waste Determination/ } \\
\text { Designation of Dangerous Waste } \\
\text { WAC 173-303--070 } \\
40 \text { CFR } 262.11\end{array}$ & $\begin{array}{l}\text { Determination must be conducted for all } \\
\text { waste streams. }\end{array}$ & $\begin{array}{l}\text { All known waste streams designated based } \\
\text { on analysis or process knowledge except } \\
\text { for refractory brick and used HEPA filters. } \\
\text { TCLP data inferred from total metal content } \\
\text { for each waste stream. }\end{array}$ & \\
\hline
\end{tabular}


Table 3. (contd)

\begin{tabular}{|c|c|c|c|}
\hline Applicable Regulation & Regulatory Requirement & Current Status & Comments \\
\hline $\begin{array}{l}\text { Manifests } \\
\text { WAC } 173-303-180 \\
40 \text { CFR } 262.21\end{array}$ & $\begin{array}{l}\text { Manifests used for offsite shipments, } \\
\text { copies onsite, required reporting. }\end{array}$ & $\begin{array}{l}\text { Manifests used for shipments to other } \\
\text { areas of Hanford Site land offsite } \\
\text { shipments). Internal tracking mechanism } \\
\text { used for shipments within } 300 \text { Area. }\end{array}$ & No waste received from offsite. \\
\hline $\begin{array}{l}\text { Annual Hazardous Waste (HW) } \\
\text { Report } \\
\text { WAC-303-380 } \\
40 \text { CFR } 265.75\end{array}$ & $\begin{array}{l}\text { Reports filed annually; unmanifested waste } \\
\text { reports filed; copies onsite. }\end{array}$ & Reports are maintained onsite. & $\begin{array}{l}\text { All facility reporting conducted } \\
\text { through Hanford Site system. }\end{array}$ \\
\hline $\begin{array}{l}\text { Export//mport Activities } \\
40 \mathrm{CFR} 262.20 \text { and } 265.12\end{array}$ & $\begin{array}{l}\text { Acknowledgement of Consent; file annual } \\
\text { report; manifests completed properly. }\end{array}$ & Not applicable to current operations. & $\begin{array}{l}\text { No waste is being imported or } \\
\text { exported from outside the United } \\
\text { States. }\end{array}$ \\
\hline $\begin{array}{l}\text { Inspection Schedule and Log } \\
\text { WAC-173-303-320 } \\
40 \text { CFR } 265.15\end{array}$ & $\begin{array}{l}\text { Inspections conducted; written schedule; } \\
\text { inspection log. }\end{array}$ & $\begin{array}{l}\text { Remote waste inspections conducted } \\
\text { weekly on containers. } \\
\text { Inspection schedule not detailed enough or } \\
\text { consolidated. } \\
\text { Visual inspection of tanks not possible; no } \\
\text { cameras. Vault tanks are monitored daily } \\
\text { for liquid level, specific gravity, and sparge } \\
\text { airflow. Data are recorded in a log. } \\
\text { Monitoring, safety and emergency equip. } \\
\text { ment is inspected regularly. } \\
\text { Inspection logs are kept. }\end{array}$ & $\begin{array}{l}\text { B-Cell interior partially visible via } \\
\text { windows and remote video, with } \\
\text { some obstruction. }\end{array}$ \\
\hline $\begin{array}{l}\text { Personnel Training Records } \\
\text { WAC 173-303-330 } \\
40 \text { CFR } 265.16\end{array}$ & $\begin{array}{l}\text { Training conducted; annual reviews; } \\
\text { written job description; records onsite. }\end{array}$ & $\begin{array}{l}\text { Current training is under PNL-wide training } \\
\text { plan. Building-specific training is being } \\
\text { implemented based on department plan. } \\
\text { Position descriptions incomplete. Plan has } \\
\text { not been fully implemented yet. }\end{array}$ & \\
\hline
\end{tabular}


Table 3. (contd)

\begin{tabular}{|c|c|c|c|}
\hline Applicable Regulation & Regulatory Requirement & Current Status & Cömmients \\
\hline $\begin{array}{l}\text { Contingency Plan } \\
\text { WAC-173-303-350 } \\
40 \text { CFR } 262.34(a)(4)\end{array}$ & $\begin{array}{l}\text { Plan onsite; arrangements with local } \\
\text { authorities; emergency procedures, coordi- } \\
\text { nators; equipment, evacuation plan. }\end{array}$ & $\begin{array}{l}\text { Contingency plan consists of. a PNL-wide } \\
\text { contingency plan plus a building-specific } \\
\text { emergency plan. Memorandums of Under- } \\
\text { standing are in place. }\end{array}$ & \\
\hline $\begin{array}{l}\text { Preparedness and Prevention } \\
\text { WAC-303-340 } \\
40 \text { CFR } 262.34(a)(4)\end{array}$ & $\begin{array}{l}\text { Accessible alarm, telephone, emergency } \\
\text { equipment; equipment maintained, acces- } \\
\text { sible; adequate aisle space; source of } \\
\text { water. }\end{array}$ & $\begin{array}{l}\text { Have internal and external communication } \\
\text { systems, fire control equipment lincluding } \\
\text { fire suppressionl, personnel protection } \\
\text { equipment, spill control supplies, Hanford } \\
\text { Facility emergency equipment, criticality } \\
\text { detectors, telephones, intercoms, fire } \\
\text { alarms. }\end{array}$ & $\begin{array}{l}\text { There is adequate aisle space in } \\
\text { work galleries surrounding cells, in } \\
\text { the hallways leading to the change } \\
\text { room, in the change room, and } \\
\text { throughout the building. } \\
\text { Since B-Cell is not accessible to } \\
\text { manned entry, aisle space require- } \\
\text { ments do not appear to be appli- } \\
\text { cable within the cell itself. }\end{array}$ \\
\hline $\begin{array}{l}\text { SARA Title III Coordination } \\
\text { WAC 173-303-355 }\end{array}$ & $\begin{array}{l}\text { Coordinate preparedness and prevention } \\
\text { planning and contingency planning efforts. }\end{array}$ & $\begin{array}{l}\text { Has been coordinated through Hanford } \\
\text { sitewide effort. }\end{array}$ & \\
\hline $\begin{array}{l}\text { Emergencies } \\
\text { WAC-173-303-360 }\end{array}$ & $\begin{array}{l}\text { Person on call, follow emergency } \\
\text { procedures. }\end{array}$ & Building Emergency Plan covers. & $\begin{array}{l}\text { One phone number }(375-2400) \text { pro- } \\
\text { vides centralized point for emer- } \\
\text { gency management, emergency } \\
\text { response dispatch and overall } \\
\text { coordination. }\end{array}$ \\
\hline $\begin{array}{l}\text { Ignitables/Reactives/ } \\
\text { Incompatibles } \\
40 \text { CFR } 265.17\end{array}$ & $\begin{array}{l}\text { Special requirements (separation of incom- } \\
\text { patibles, distance from source of ignition, } \\
\text { etc.). }\end{array}$ & $\begin{array}{l}\text { No ignitables, reactives or incompatibles } \\
\text { present in REC or HLV. }\end{array}$ & \\
\hline $\begin{array}{l}\text { Waste Analysis Plan } \\
\text { WAC-173-303-300 } \\
40 \text { CFR } 265.13(b)\end{array}$ & $\begin{array}{l}\text { Plan onsite, includes parameters, test } \\
\text { methods, sampling methods, frequency; } \\
\text { results onsite. }\end{array}$ & $\begin{array}{l}\text { Detailed knowledge is available on com- } \\
\text { position. Waste analysis plan has been } \\
\text { updated and is being routed for approvals. }\end{array}$ & $\begin{array}{l}\text { No offsite waste received. Repeat } \\
\text { analysis not needed because wastes } \\
\text { are not being generated. }\end{array}$ \\
\hline
\end{tabular}


Table 3. (contd)

\begin{tabular}{|c|c|c|c|}
\hline Applicable Regulation & Regulatory Requirement & Current Status & Comments \\
\hline $\begin{array}{l}\text { Operating Records } \\
40 \text { CFR } 265.73 \text { and } \\
265.94(a)(1)\end{array}$ & $\begin{array}{l}\text { Records onsite: waste description, } \\
\text { quantity, inventory, analytical results, } \\
\text { reports of contingency plan implementa- } \\
\text { tion, results of inspections, closure cost } \\
\text { estimate. }\end{array}$ & $\begin{array}{l}\text { Records appear to be complete, but are not } \\
\text { located in one place in the } 300 \text { Area. }\end{array}$ & \\
\hline $\begin{array}{l}\text { Closure Plan } \\
40 \text { CFR } 265.110-120\end{array}$ & $\begin{array}{l}\text { Closure certification; plan onsite; all regu- } \\
\text { lated units covered; includes inventory, } \\
\text { description of closure, schedule. }\end{array}$ & $\begin{array}{l}\text { A closure plan has not been prepared. } \\
\text { Estimate of closure date depends upon } \\
\text { evaluation of technical alternatives. }\end{array}$ & \\
\hline $\begin{array}{l}\text { Post-Closure Plan } \\
40 \text { CFR } 265.117,119\end{array}$ & $\begin{array}{l}\text { Plan onsite, includes monitoring activities, } \\
\text { maintenance and inspection, contact, } \\
\text { length of post-closure period. }\end{array}$ & $\begin{array}{l}\text { No post-closure plan. Will be required if } \\
\text { site closes as a landfill. }\end{array}$ & \\
\hline $\begin{array}{l}\text { Financial Requirements } \\
40 \text { CFR } 265.142\end{array}$ & $\begin{array}{l}\text { Closure and post-closure cost estimates } \\
\text { and financial assurance/liability insurance. }\end{array}$ & Not applicable. & $\begin{array}{l}\text { Federal government and federal facil- } \\
\text { ities exempt. }\end{array}$ \\
\hline $\begin{array}{l}\text { Site Security } \\
\text { WAC } 173-303-310 \\
40 \text { CFR } 265.14\end{array}$ & $\begin{array}{l}\text { 24-hour surveillance or barrier and means } \\
\text { to control entry, signs. }\end{array}$ & $\begin{array}{l}\text { Building is either locked or has a security } \\
\text { representative present. Access to waste } \\
\text { management areas inside building } \\
\text { controlled through postings and locked } \\
\text { doors. Access to HLV further prevented by } \\
\text { thick concrete blocks covering vault. }\end{array}$ & $\begin{array}{l}\text { Fences are open and unmanned but } \\
\text { have random patrols and postings; } \\
\text { ID and clearance required to enter } \\
\text { building. }\end{array}$ \\
\hline $\begin{array}{l}\text { Satellite Accumulation } \\
40 \text { CFR } 262.34(c)(1)\end{array}$ & $\begin{array}{l}\text { Less than } 55 \text { gal per waste stream; con- } \\
\text { tainers marked and contents described; } \\
\text { closed when not in use. }\end{array}$ & $\begin{array}{l}\text { Satellite accumulation areas in truck lock } \\
\text { and room } 147 \text { meets requirements. } \\
\text { "Satellite" accumulation in B-Cell (managed } \\
\text { as a satellite area) meets quantity limit, but } \\
\text { materials are neither fully consolidated nor } \\
\text { in closed containers. }\end{array}$ & $\begin{array}{l}\text { Materials in satellite accumulation } \\
\text { area in B-Cell cannot be put in } \\
\text { closed containers due to hydrogen } \\
\text { generation. }\end{array}$ \\
\hline $\begin{array}{l}\text { Containers } \\
40 \text { CFR } 265.170-177\end{array}$ & $\begin{array}{l}\text { Impermeable base; containment; manage- } \\
\text { ment (condition, closed when not in use, } \\
\text { buffer zone for ignitable/reactive, } \\
\text { incompatibles separated, storage } \\
<90 \text { days). }\end{array}$ & $\begin{array}{l}\text { Containers are in good condition. Con- } \\
\text { tainers inspected weekly. Drums are not } \\
\text { tightly sealed due to gas generation. } \\
\text { Cell walls and floor lined with stainless } \\
\text { steel provide containment, sloped floor not } \\
\text { required for solids. }\end{array}$ & \\
\hline
\end{tabular}


Table 3. (contd)

\begin{tabular}{|c|c|c|c|}
\hline Appliciable Regulation & Regulatory Requiremẹt & Current Stätus & Comments \\
\hline $\begin{array}{l}\text { Other Pre-transport } \\
\text { Requirements } \\
40 \text { CFR 262.30-34 }\end{array}$ & $\begin{array}{l}\text { Packaging, labeling, marking, proper DOT } \\
\text { shipping name, contents described, } \\
\text { accumulation date. }\end{array}$ & $\begin{array}{l}\text { Containers have been painted with identify- } \\
\text { ing numbers keyed to log. Labeling and } \\
\text { marking does not meet RCRA requiremeints. }\end{array}$ & $\begin{array}{l}\text { Painting must be done by manipu- } \\
\text { lator inside cells. High radiation } \\
\text { fields tend to degrade paint and ink. }\end{array}$ \\
\hline $\begin{array}{l}\text { Waste Tanks } \\
40 \text { CFR } 265.190-201,262.34\end{array}$ & $\begin{array}{l}\text { Secondary containment; leak detection } \\
\text { system; corrosion protection system; } \\
\text { special requirements for ignitable/reactive } \\
\text { waste; marking, no releases; releases } \\
\text { reported; certification of repairs; tank } \\
\text { integrity assessment. }\end{array}$ & $\begin{array}{l}\text { Vault serves as secondary containment } \\
\text { (lined with stainless steel, seams welded). } \\
\text { HLV has sloped floor to sump with alarm. } \\
\text { Tanks constructed of corrosion-resistant } \\
\text { material. When installed, tanks underwent } \\
\text { non-destructive examination and leak tests. } \\
\text { Have plans for tank integrity assessment. }\end{array}$ & $\begin{array}{l}\text { Tank contents are identified in the } \\
\text { sampling area. Need to address } \\
\text { unique problems associated with } \\
\text { labeling and tank integrity } \\
\text { assessment in high radiation field. }\end{array}$ \\
\hline $\begin{array}{l}\text { Surface Impoundments } \\
40 \text { CFR } 265.220-230\end{array}$ & $\begin{array}{l}\text { Excavation, depression, or diked area to } \\
\text { hold an accumulation of liquid regulated } \\
\text { wastes. }\end{array}$ & Not applicable to current operations. & \\
\hline $\begin{array}{l}\text { Waste Piles } \\
40 \text { CFR } 265.250 \cdot 257\end{array}$ & $\begin{array}{l}\text { Non-containerized (outside) accumulation } \\
\text { of regulated waste materials used for } \\
\text { treatment or storage. }\end{array}$ & Not applicable to current operations. & - \\
\hline $\begin{array}{l}\text { Landfills } \\
40 \text { CFR } 265.301-315\end{array}$ & $\begin{array}{l}\text { Placement of regulated waste in or on } \\
\text { land, other than piles, land treatment } \\
\text { facility or other special situation. }\end{array}$ & Not applicable to current operations. & \\
\hline $\begin{array}{l}\text { Land Treatment } \\
40 \text { CFR } 265 \text { Subpart M }\end{array}$ & $\begin{array}{l}\text { Application of regulated waste onto or } \\
\text { incorporation into soil surface }\end{array}$ & Not applicable to current operations. & \\
\hline $\begin{array}{l}\text { Incinerators, /Thermal Treatment } \\
40 \text { CFR 265.340-345 }\end{array}$ & $\begin{array}{l}\text { Enclosed device for burning of hazardous } \\
\text { or mixed waste. }\end{array}$ & Not applicable to current operations. & \\
\hline $\begin{array}{l}\text { Chemical, Physical, Biological } \\
\text { Treatment } \\
40 \text { CFR } 265 \text { Subpart Q }\end{array}$ & $\begin{array}{l}\text { Treatment of regulated waste by chemical, } \\
\text { physical or blological methods in other } \\
\text { than tanks, impoundments, or land } \\
\text { treatment facilities. }\end{array}$ & Not applicable to current operations. & \\
\hline $\begin{array}{l}\text { Underground Injection } \\
40 \text { CFR } 265 \text { Subpart R }\end{array}$ & $\begin{array}{l}\text { Subsurface emplacement of regulated } \\
\text { waste through a well. }\end{array}$ & Not applicable to current operations. & \\
\hline
\end{tabular}


Table 3. (contd)

\begin{tabular}{|l|l|l||}
\hline \multicolumn{1}{|c|}{ Applicable Regulation } & \multicolumn{1}{|c|}{ Regulatory Requirement } & \multicolumn{1}{|c|}{ Current Status } \\
\hline $\begin{array}{l}\text { Miscellaneous Units } \\
40 \text { CFR } 265 \text { Subpart X }\end{array}$ & $\begin{array}{l}\text { Regulated waste management units that } \\
\text { do not qualify as containers, tanks or other } \\
\text { "conventional" units. }\end{array}$ & Not applicable to current operations. \\
\hline $\begin{array}{l}\text { Recycle/Reclaim } \\
40 \text { CFR } 266\end{array}$ & $\begin{array}{l}\text { Accumulation for recycling less than } \\
1 \text { vear, accumulation date, clearly marked } \\
\text { and labeled, documentation on potential } \\
\text { for recycling/reclamation/reuse. }\end{array}$ & Not applicable to current operations. \\
\hline $\begin{array}{l}\text { Hazardous Waste Transportation } \\
40 \text { CFR 263 }\end{array}$ & $\begin{array}{l}\text { Offsite transportation of manifested waste } \\
\text { 40 CFR Subpart F }\end{array}$ & Not applicable to current operations. \\
\hline \begin{tabular}{l} 
Ground Water Monitoring \\
\hline
\end{tabular} & $\begin{array}{l}\text { Applies to surface impoundments, landfills, } \\
\text { and land treatment facilities }\end{array}$ & $\begin{array}{l}\text { Not applicable to current operations. } \\
\text { ress transportation issues. Mixed } \\
\text { Waste is expected to be transported } \\
\text { to the 200 Area. }\end{array}$ \\
\hline
\end{tabular}




\section{Conclusion}

Like most mixed waste at Hanford and elsewhere in the DOE complex, the REC/HLV mixed waste is being held in structures designed before the passage of RCRA and was largely generated before the application of RCRA to radioactive waste was considered. The materials in REC/HLV are currently stable and secure. Criticality concerns are managed through established radioactive materials handling and containment practices.

Nonetheless, mixed waste management in REC/HLV is not in full compliance with RCRA regulations. Because of the proximity of the Columbia River and the unacceptable safety risks to the general public posed by a significant seismic event, the mixed waste in $324 \mathrm{~B}-\mathrm{Cell}$ is of serious concern. Notwithstanding the lack of RCRA storage facilities for remote-handled mixed waste at Hanford or elsewhere in the nation, it is preferable to remove mixed waste from the $324 \mathrm{~B}-$ Cell and store it in a location away from the river, such as the 200 Area.

Technical options must and are being developed to accomplish this removal as quickly as feasible. In the meantime, best efforts must be made, given health and safety concerns and technical limitations, to provide the best practicable safeguards and procedures to address the health, safety, and environmental protection purposes of each of the RCRA requirements. The Department of Ecology and EPA will be closely consulted throughout the development and implementation of all cleanup and closure actions, and the Indian Nations and appropriate stakeholders will be fully apprised of the problems, technical solutions, and progress.

For more information, contact the following individuals at the Hanford Site:

Mary Vargas

Laboratory Management Division, DOE-RL

509-372-4994

Walt Apley

Nuclear Facilities Manager ${ }_{i}$ PNL

509-373-9468

Michael Schlender

324 RCRA Compliance Program Manager, PNL

509-376-8795 


\section{Appendix A}

\section{Locator and Topographical Maps of Building 324}

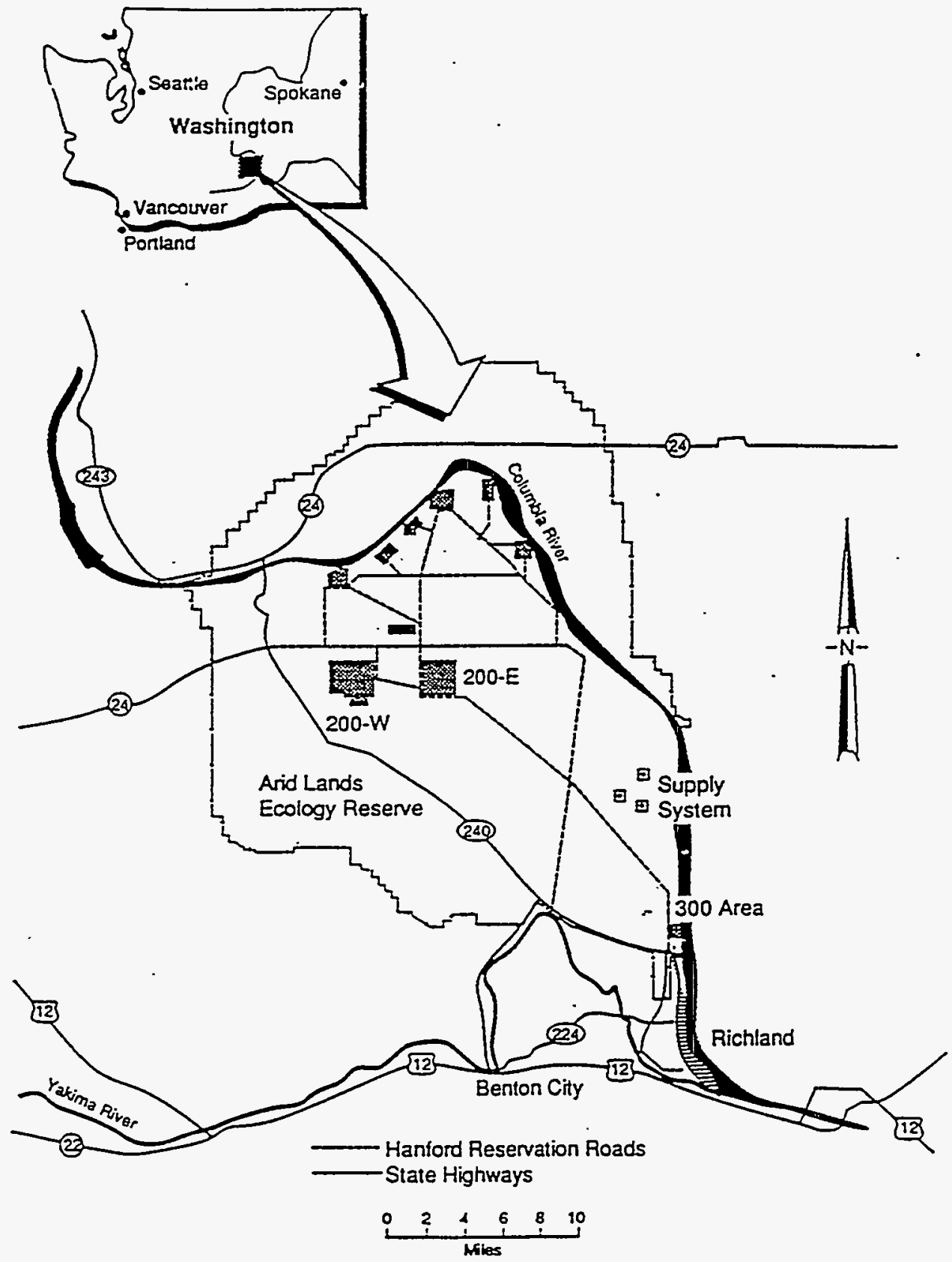

Figure A.1. Map of Hanford Site 


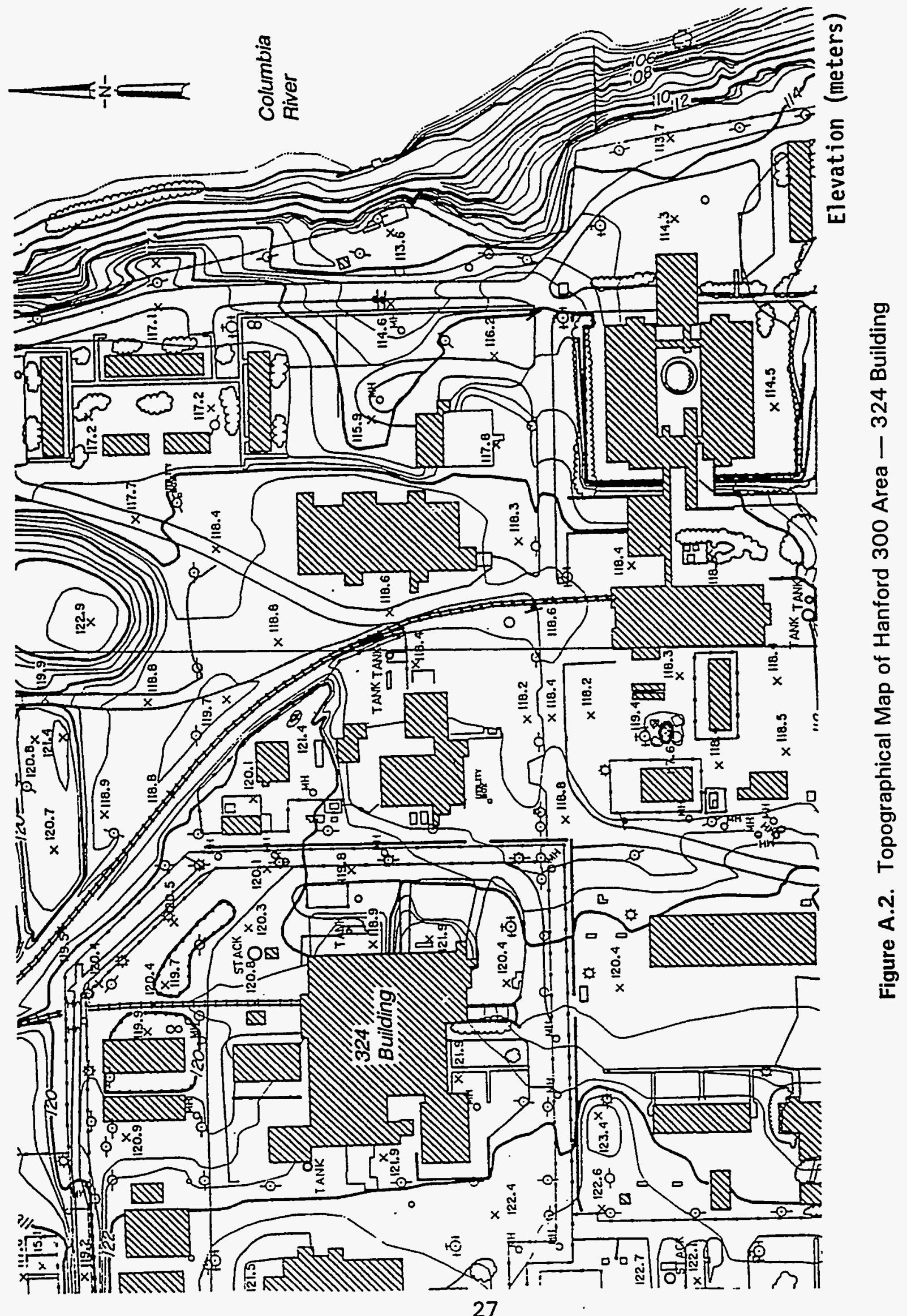




\section{Appendix B}

\section{Design Information on the B-Cell}

B-Cell is the largest hot cell in the REC. It measures $23 \mathrm{ft} \times 25 \mathrm{ft} \times 30 \mathrm{ft}$ (height). The cell is serviced by a remotely operated cranes with a capacity of 6 tons.

The air inlet into B-Cell was $85 \%$ dust stop filtered until April 1994. At that time, the inlet dust stop filters were replaced with HEPA filters.

Exhaust air filtration has been upgraded several times over the years. Currently, the air exhaust from B-Cell is filtered through an electrostatic precipitator and an in-cell HEPA filter bank. The remaining cells are filtered through dust stop filters. Ventilation system air from each cell exits through the 324 Building's final stage HEPA filter system. 


\section{Appendix C}

\section{Vault Tanks}

The LLV contains Tanks 101, 102, 103, and 108. The HLV contains Tanks 104, 105, 106 , and 107.

LLV Tanks 101 and 102 are used to transfer radioactive liquid waste to the double shell HLW tanks in the 200 Area via the 340 Building (RLWS operated by WHC). Mixed waste has been transferred through these tanks. Liquids can be transferred from the hot cells to the HLV tanks, then to the LLV tanks, and on to the 340 facility through existing piping systems. Transfers to the 340 receiving facility meet WHC acceptance criteria.

Tanks 103, 106 and 108 do not currently contain mixed waste (designation based on process knowledge and analytical data). Only Tanks 104, 105 and 107 (in the HLV) contain mixed waste.

Two shielded, below-grade vaults are equipped for temporary storage of radioactive liquid wastes and other solutions generated within the 324 facility. The HLV (Room 16), located under the floor of the Cask Handling Area, is used for the storage of high-activity wastes. HLV dimensions are $21 \mathrm{ft} \times 13 \mathrm{ft} \times 14.5 \mathrm{ft}$. The LLV (Room 17) is used for low to intermediate level wastes. Each vault contains four stainless steel tanks with capacities ranging from $450-5,000 \mathrm{gal}$.

Tanks and ancillary piping are corrosion-resistant austenitic stainless steel. Pipe connections are welded. Tanks have only top-entering penetrations to avoid leaky side fittings. There is secondary containment around tanks and piping (see body of paper). Instruments are used to control the fill level of the tanks and to detect leaks.

Tk-104 was built in 1954 and installed in the 321 Building. In 1964, it was modified and moved to the 324 Building. All circumferential shell and long seam seals were completely radiographed at that time. It was also leak-tested with water after modifications. The tank is $9.0 \mathrm{ft}$ in diameter and $8.9 \mathrm{ft}$ high and has a design capacity of $3912 \mathrm{gal}$. It is constructed of 0.5 in.-thick $304 \mathrm{~L}$ stainless steel.

Tk-105 was built in 1943, but was not used until 1950 (in the 321 Building). In 1964 , the tank was modified and moved to the 324 Building. At that time it was radiographed and hydrostatically tested. The tank is $9.5 \mathrm{ft}$ in diameter and $8.88 \mathrm{ft}$ high. Tk-105 has a design capacity of $4792 \mathrm{gal}$. It is constructed of 0.5 in.-thick 309 SCB stainless steel. 
Tk-107 is $5.5 \mathrm{ft}$ in diameter and $6 \mathrm{ft}$ in height. Tk-107 has a design capacity of $958 \mathrm{gal}$. It is constructed of $0.25 \mathrm{in}$.-thick $304 \mathrm{~L}$ stainless steel.

Ancillary equipment is constructed of 1.5-in. to 2-in. diameter stainless steel pipe with welded joints. Piping is above tanks. When piping passes through concrete, it is enclosed in 4-in. diameter fiberglass reinforced epoxy pipe. All piping has been pressure-tested.

Tanks are fitted with manometers for measuring liquid level, specific gravity, and tank static pressure. They are also equipped with high liquid level and high temperature alarms. Vault tanks are vented through a common vessel vent system that pulls air and tank vapors through two HEPA filters and discharges to the building ventilation stack.

Each vault is lined with stainless steel plates which are seal-welded to provide secondary containment. The floor of each vault is sloped to a sump which has a liquid detection system that alarms if any.liquid is present, indicating a tank leak. 


\section{Appendix D}

\section{Relevant Tri-Party Agreement Milestones}

There are no existing Tri-Party Agreement (TPA) milestones which directly relate to the 324 Building REC, with the possible exception of the Part B submittal milestones M-20-42 (Thermal Treatment Test Facilities) and M-20-43 (Physical and Chemical Treatment Test Facilities). These test facility milestones (currently set for 12-94, but the subject of submitted change requests) and the scope of the associated Part A's are currently under negotiation. However, there are TPA milestones currently being negotiated by DOE under newly proposed milestone M-89 to complete the 324 Building REC/HLV cleanout/closure.

Major milestone M-89 includes both interim and final actions to complete the closure of these two solid waste management units. M-89 includes interim milestones for a compliance plan and schedule, a Project Management Plan for the BCCP, an assessment of waste disposition options, and completion of a clean closure feasibility study leading to the preparation and submittal of a closure plan for the waste management units. An interim milestone is to estimate the final date of closure based on the results of studies contributing to the closure plan development. 


\section{Appendix E}

\section{Materials Reviewed}

Information contained in this white paper was compiled and summarized from a number of sources. The following documents can be referred to for more detailed information. All of these documents were submitted to the Department of Ecology on April 27, 1994.

Correspondence between PNL and DOE regarding mixed waste issues in the 324 Building:

1. Letter from JL McElroy, PNL, to JJ Sutey, DOE, dated October 28, 1992, "POTENTIAL RADIOACTIVE MIXED WASTE IN THE 324 BUILDING B-CELL."

2. Letter from JJ Sutey, DOE, to Director, PNL, dated December 3, 1992, 92-POS-529, "REQUEST FOR REGULATORY ANALYSIS, PLAN AND SCHEDULE FOR MANAGEMENT OF MIXED WASTE IN THE 324 BUILDING B-CELL."

3. Letter from JL McElroy, PNL, to JJ Sutey, DOE, dated December 21, 1992, "REGULATORY ANALYSIS, PLAN AND SCHEDULE FOR MANAGEMENT OF MIXED WASTE IN THE 324 BUILDING B-CELL."

4. Letter from WJ Apley, PNL, to JD Bauer, DOE, dated April 26, 1993, "NOTIFICATION OF RESULTS OF LABORATORY ANALYSIS OF POTENTIAL HIGH-ACTIVITY RADIOACTIVE MIXED WASTE."

5. Letter from WJ Apley, PNL, to JJ Sutey, DOE, dated May 18, 1993, "MANAGEMENT STRATEGY FOR WASTES IN THE 324 BUILDING B-CELL AND HIGH-LEVEL VAULT TANKS."

6. Letter from WJ Apley, PNL, to JJ Sutey, DOE, dated June 3, 1993, "NOTIFICATION OF NONCOMPLIANCE WITH STORAGE REQUIREMENTS FOR HIGH-ACTIVITY RADIOACTIVE MIXED WASTE STARTING 90 DAYS FROM JUNE 10, 1993."

7. Letter from JJ Sutey, DOE, to Director, PNL, dated June 21, 1993, 93-LMD-227, "PNL MANAGEMENT OF RADIOACTIVE MIXED WASTE (RMW) IN THE 324 BUILDING HOT CELL." 
8. Letter from WJ Apley, PNL, to JJ Sutey, DOE, dated June 25, 1993, "DATE FOR DRY RUN PRESENTATION ON STATUS AND RECOMMENDED STRATEGY FOR MANAGEMENT OF RADIOACTIVE MIXED WASTE (RMW) IN 324 BUILDING HOT CELL."

9. Letter from DE Knowlton, PNL, to WH Hamilton, Jr., WHC, dated February 23, 1994, "CAPACITY REQUIRED FOR SPECIAL CASE WASTE (SCW) AND MIXED WASTE (MW) STORAGE RELATED TO THE 324 BUILDING HOT-CELL CLEANOUT."

10. Letter from BD Shipp, PNL, to JJ Sutey, DOE, dated March 3, 1994, "NOTIFICATION OF NONCOMPLIANCE WITH STORAGE REQUIREMENTS FOR HIGH-ACTIVITY RADIOACTIVE MIXED WASTE STARTING 90 DAYS FROM FEBRUARY 14, 1993."

Other documents relating to mixed waste management activities in the 324 Building.

Materials in the 324 Building High-level Vault Tanks.

- Engineering Technology Center Environmental, Safety, and Health (ES\&H) Plan CY-94

- FRG Information Package (10 documents)

- Manifests for lead shipments to the Central Waste Complex.

Estimated Quantities and Compositions of Materials Processed During Research and Development Activities in B-Cell Since 1980.

Letter from HC Burkholder, PNL, to KA Gasper, Rockwell, dated August 17, 1984, "RADIOLYTIC HYDROGEN GENERATION DURING TRANSPORT AND HANDLING OF THE 30-TON BOWLING BALL CASKS."

Processing Summary Report: Fabrication of Cesium and Strontium of Heat and Radiation Sources - February 1989.

324 Building Hot Cell Restoration Program: Radioactive Mixed Waste Management - Draft, October 1992.

Waste Designation Study of the FRG Canisters - December 13, 1993.

324 Building Hot Cell Operations Training Manual - Draft, January 1994.

"Evaluation of Regulatory Options for Storing High-Activity Mixed Waste in B-Cell," February 24, 1994, report prepared for PNL by AT Kearney. 
Mixed Waste Management Plan for the 324 Building Radiochemical Engineering Cells (REC) and Tank Vaults, March 22, 1994, report prepared for PNL by AT Kearney.

Mixed Waste Management Plan for the B-Cell Cleanout Project - March 25, 1994.

Remote Systems Technology Department Training Plan - April 1994. 


\section{Distribution}

No. of

Copies

\section{OFFSITE}

2 Office of Scientific and Technical Information

\section{ONSITE}

$16 \mathrm{DOE} / \mathrm{RL}$

PNLMHC/MACTEC

W. J. Apley

W. J. Bjorklund

D. S. Broussard

J. F. Donaghue

E. A. Flores

J. T. Fulton

S. W. Gajewski

E. M. Greager
No. of

Copies

K. L. Hoewing

T. Y. Hosaka

J. H. Jarrett

S. L. Jones

Y. B. Katayama

D. E. Knowiton

S. J. Kowall

D. A. Lamar

D. K. Lutter

W. J. Madia

H. D. Massey

M. J. Riess

W. A. Ross

M. H. Schlender

B. D. Shipp

H. T. Tilden

J. L. Waite

P. J. Weaver

H. H. Van Tuyl 